\title{
Geotechnical and Geological Analysis of Amuzukwu Landslide
}

\author{
Emmanuel Emeka Arinze*, Ugochukwu Nnatuanya Okonkwo, Samad Opeyemi Afolabi, \\ Chioma Margaret Ahaiwe, Michael Oduh Ojobo
}

Department of Civil Engineering, Michael Okpara University of Agriculture, Umduike, Nigeria

Email address:

emmanuel.arinze@mouau.edu.ng (E. E. Arinze)

${ }^{*}$ Corresponding author

\section{To cite this article:}

Emmanuel Emeka Arinze, Ugochukwu Nnatuanya Okonkwo, Samad Opeyemi Afolabi, Chioma Margaret Ahaiwe, Michael Oduh Ojobo. Geotechnical and Geological Analysis of Amuzukwu Landslide. American Journal of Environmental Protection.

Vol. 10, No. 4, 2021, pp. 84-89. doi: 10.11648/j.ajep.20211004.12

Received: July 6, 2021; Accepted: July 23, 2021; Published: August 18, 2021

\begin{abstract}
Landslides are present in all continents playing important role in the continual evolution of this type of or similar geohazard. They constitute a serious hazard in many areas of the world. The landslide event can be single or multiple. This paper involves the geotechnical analysis of landslide that occurred in Amuzukwu Abia State Nigeria. Amuzukwu landslide of about volume $3.5 \times 10^{4} \mathrm{~m}^{2}$ which was classified as rotational has a detached surface which is roughly circular and spoon-like. The paper also discussed the manifestation, causes and effect of landslide. For geotechnical analysis, samples were collected from the site of the landslide and subjected to the following soil tests: natural moisture content, specific gravity, relative density, Atterberg limits, sieve analysis, compaction, permeability, shear strength, and unit weight. Slopes adjacent to the slides that are still intact were also analyzed using Plaxis 2D to determine their factors of safety. Both the geotechnical laboratory results and Plaxis 2D results reveal that another landslide is inevitable if the conditions of the infinite slope is not improved using the methods recommended in this paper. Some of the methods recommended include cutting back of slope to reduce its gradient, reinforcement (using Reinforced concrete), soil nailing as well as anchors and retaining structures.
\end{abstract}

Keywords: Amuzukwu Landslide, Rotational Slide, Geotechnical and Geological Analysis, Plaxis 2D, Geohazard

\section{Introduction}

\subsection{Background}

A landslide can be defined as the movement of rocks, detritus, or soil caused by the action of gravity [1]. It also involves rapid displacement of rock mass, residual soils, or sediments adjoining a slope [2-3]. According to [4], landslides are classified according to the type of movement (topples, slumps, sags, flow, slides, falls), material composition (silt, rock, unconsolidated sediments) and speed (slow, moderate, fast). Landslides are major categories of natural disaster that can lead to huge casualties and economic losses in the affected areas [5-6]. In United States, It causes an estimated $\$ 3.5$ billion damages and 25 to 50 deaths annually [7]. Globally, between 2004 and 2010, 2620 fatal slides were recorded which resulted in 32,322 deaths [8].

Landslide is occasioned by terrain instability, and for this reason, it is important in geotechnical practice to analyze the stability of slope. Gravity would tend to flatten out slopes. However, the stability conditions may change due to temporal adjustments of equilibrium position or because of external perturbations. Water is one of the most contributing factors to instability. It decreases cohesion in soils and increases weight and pore water as well as the gravitational driving forces in slopes [4]. Seepage through slopes may be critical. High rate of seepage may trigger instability [9]. Landslides may be triggered by heavy storms, earthquake, volcanic eruption, geological factors, climatic change, and erosion by glacier or river and human activities [10-13]. Climate changes affects the stability of slopes, especially infinite slopes [14]. However, it is less clear the extent, magnitude and direction the climatic changes impact on slopes [15]. The most important cause of landslide can be linked to geology, failure generally occurs on weak planes in rock, including stratification, foliation, joints or faults and 
poorly lithified rocks and non-lithified sediments are more susceptible to failure than lithified materials. Water also permeates joints, fractures and permeable strata elevating pore pressures to the threshold of collapse. In the case of human activities, erecting structures on top of unstable slope or excavating its base may initiate landslide, because it increases gravitational driving force on the slope [1].

The application of landslide prediction models has of late increased because reliable landslide risk maps with robust time prediction capability are needed for near perfect analysis of landslide [16-17], and many models have been used in analysis and prediction of the geohazard [18-24]. The major factor that controls the prediction capabilities of the model predictions is the detailed geotechnical properties of the constituent soil and rock $(5,3)$. The understanding of the spatial distribution of the geotechnical and geological input parameters aids the application of models over vast areas [10, 25-26]. That is why the geotechnical analysis of Amuzukwu landslide is needed since it is a prerequisite to the landslide prediction models and instrumentations.

\subsection{Study Area}

Amuzukwu is a suburb Umuahia North Local Government Area of Abia State. The gully erosion contributing mostly to the landslide passed tangentially through Amuzukwu Mbom Road. It is geographically located within the

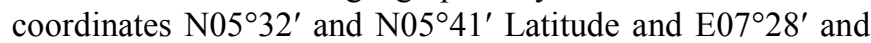
E0 $7^{\circ} 32^{\prime}$ Longitude. Figure 1 shows the township map of Amuzukwu and neighbouring communities highlighting settlements and road networks [27].

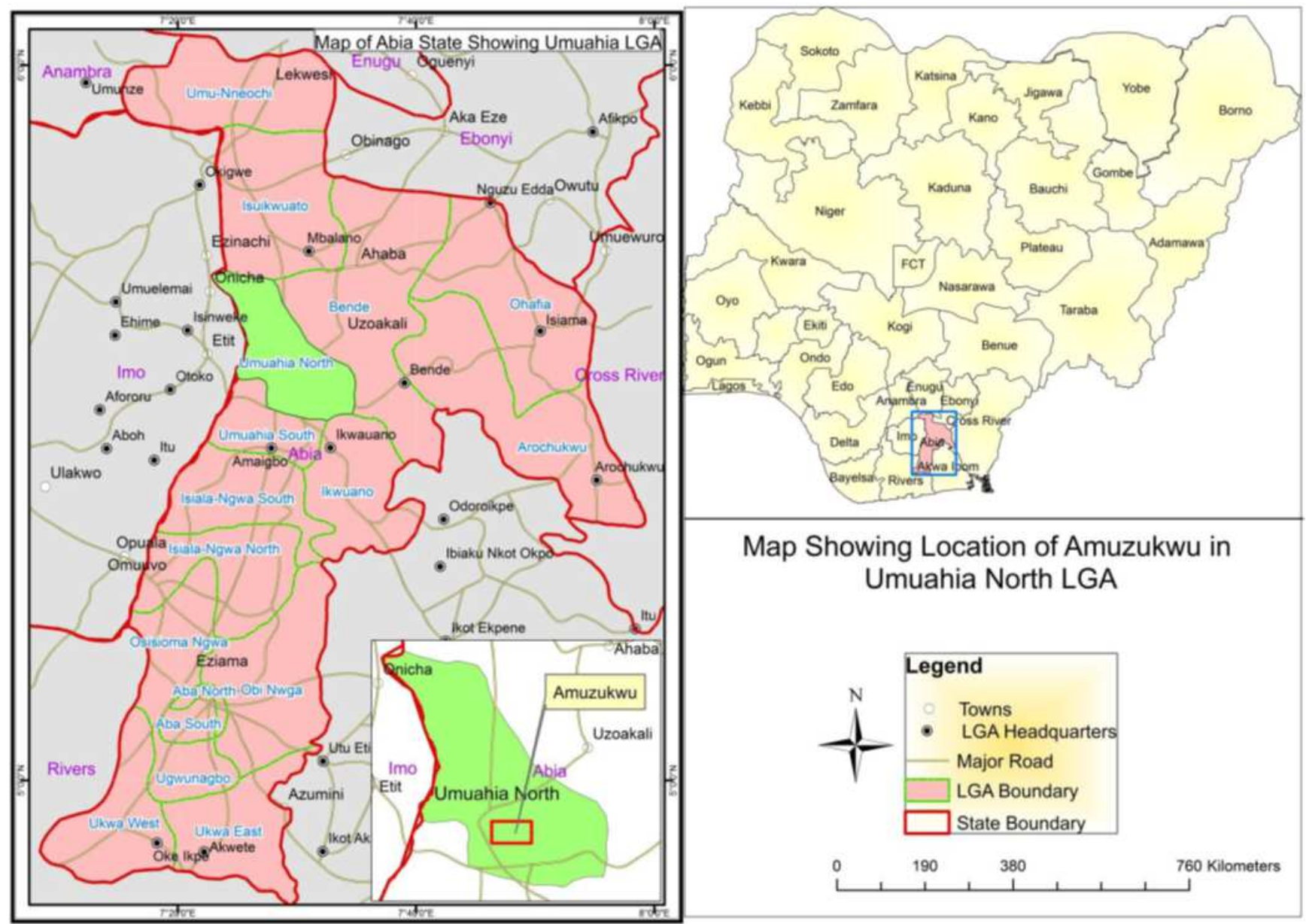

Source: NEWMAP (2015)

Figure 1. Map Showing Location of Amuzukwu in Umuahia North LGA.

\subsection{Climate}

Amuzukwu has a tropical weather. The average annual temperature in Amuzukwu is $27^{\circ} \mathrm{C}$. The rainfall intensity of about $2135 \mathrm{~mm}$ is recorded annually which encourages gully erosion and landslide. The peak of the precipitation occurs between July and September.

\section{Properties and Features of the Landslide}

Amuzukwu landslide of about volume $3.5 \times 10^{4} \mathrm{~m}^{2}$ occurred on 29th October 2019. The soil mass collapsed from the peak of a gully slope destroying a building and about 
$1120 \mathrm{~m}^{2}$ farmland. In the landslide which is classified as rotational, the detached surface is roughly circular and spoon-like. The circular shape was created by the falling mass which collapsed into a deep gully behind it. Figure 2 shows the site of the slide and areas was analyzed for stability using Plaxis 8.6. The tension cracks in the soil shown in Figure 3 which is still existing indicates stability implying that another landslide is building up except if something is done urgently to mitigate the impending disaster that might be more severe.

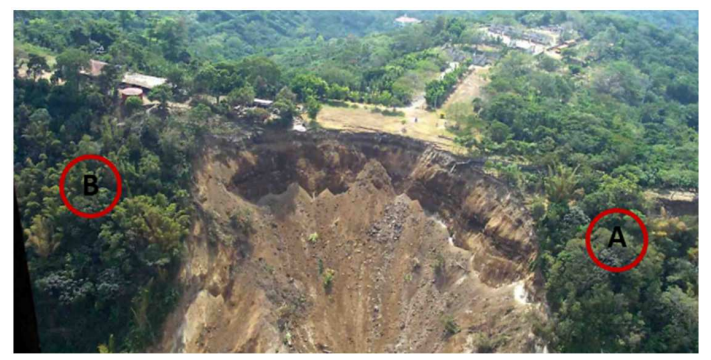

Figure 2. Landslide site at Amuzukwu.

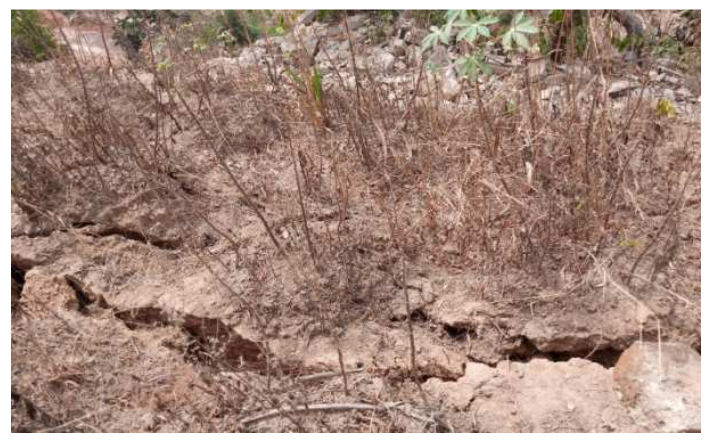

Figure 3. Cracks on the land adjacent to the landslide.

\section{Geotechnical Test Results and Discussion}

Samples were collected from 10 different points around the slope and subjected to the following test: natural moisture content, specific gravity, relative density, Atterberg limits, sieve analysis, compaction, permeability, shear strength, and unit weight. The ranges of each parameter tested are tabulated in Table 1.

Table 1. Results of the technical test.

\begin{tabular}{ll}
\hline Test & Range of Values \\
\hline Natural moisture content $(\%)$ & $8.9-12$ \\
Specific gravity & $2.50-2.55$ \\
Relative density (\%) & $25-33$ \\
Liquid limit (\%) & $32-35$ \\
Plastic limit (\%) & $20-25$ \\
Plasticity index $(\%)$ & $10-13$ \\
$\%$ passing through sieve no. 200 & $48-52$ \\
Compaction $\left(\mathrm{kg} / \mathrm{m}^{3}\right)$ & $2100-2130$ \\
OMC $(\%)$ & $12.6-13.4$ \\
Permeability & $(1-2) \mathrm{X} 10^{-4}$ \\
Cohesion $\left(\mathrm{kN} / \mathrm{m}^{2}\right)$ & $4-10$ \\
Angle of internal friction $\left({ }^{\circ}\right)$ & $17-18$ \\
Unit weight $\left(\mathrm{kN} / \mathrm{m}^{3}\right)$ & $16-19$ \\
\hline
\end{tabular}

\subsection{Specific Gravity}

Specific gravity is the ratio of mass of soil solids to the mass of an equal volume of water [28]. Typical values of specific gravity are given in Table 2 .

Table 2. Typical values of specific gravity (Bowles, 2012).

\begin{tabular}{ll}
\hline Type of Soil & Specific Gravity \\
\hline Sand & $2.65-2.67$ \\
Silty sand & $2.67-2.70$ \\
Inorganic clay & $2.70-2.80$ \\
Soil with mica/iron & $2.75-3.00$ \\
Organic soil & $1.00-2.60$ \\
\hline
\end{tabular}

According to [28], increased in specific gravity can increase the shear strength. The specific gravity obtained indicates that the soil contains a meaningful amount of inorganic soil encouraging instability of the soil.

\subsection{Relative Density}

This is an index that quantifies the degree of packing between the loosest and density possible state of coarsegrained soils [29]. The description of soil based on relative density and porosity is given in Table 3 .

Table 3. Characteristics of soils based on relative density and porosity (Budhu, 2011).

\begin{tabular}{lll}
\hline Relative Density (Dr) (\%) & Porosity n (\%) & Description \\
\hline $0-20$ & $100-80$ & Very loose \\
$20-40$ & $80-60$ & Loose \\
$40-70$ & $60-30$ & Medium dense or firm \\
$70-85$ & $30-15$ & Dense \\
$85-100$ & 45 & Very dense \\
\hline
\end{tabular}

The values of $73 \%$ and $32 \%$ obtain for the relative density and porosity respectively points to the fact that the soil is loose and prune to collapse on little agitation or external forces.

\subsection{Consistency Limits}

The consistency of a plastic soil is meaningful influences by the water content of soil. A gradual increase in moisture content causes the soil to change from the liquid state to a plastic state, from the plastic to a semi-solid state, and finally to the solid-state.

The moisture content at which soil changes from semisolid to plastic state is known as plastic limit (PL) whereas the moisture content at which soil changes from plastic to a liquid state is known as liquid limit (LL). The plasticity index (PI) is given by;

$$
P I=L L-P L
$$

Table 4 indicates typical Atterberg limits for soil.

Table 4. Typical Atterberg limits for soils.

\begin{tabular}{llll}
\hline Soil Type & LL\% & PL\% & PI \\
\hline Sand & Non & Plastic & \\
Silt & $30-40$ & $20-25$ & $10-15$ \\
Clay & $40-150$ & $25-50$ & $15-100$ \\
\hline
\end{tabular}


The values of liquid limits, plastic limits and plasticity indices obtain shows that the soil mass is predominantly silt. This points the fact the soil lacks enough of plastic soil that ensures shear strength and stability.

\subsection{Compaction}

Soil compaction is the densification of soil through the expulsion of air using mechanical means. Soil compaction increases the unit weight shear strength and bearing capacity of soil. It reduces void ratio, permeability and settlements. The typical values of optimum moisture content (OMC) and maximum dry density (MDD) are given in table 5 .

Table 5. Type of soil standard proctor compaction.

\begin{tabular}{lll}
\hline Material & MDD $\left(\mathbf{k g} / \mathbf{m}^{\mathbf{3}}\right)$ & OMC \\
\hline Clayey soil & 1555 & 28 \\
Silty soil & 1670 & 21 \\
Sandy clay & 1840 & 14 \\
Sand & 1940 & 11 \\
Gravel, sand \& clay & 2070 & 9 \\
\hline
\end{tabular}

Source: O'Flaherty (2002, Highways: The location, design, construction and maintenance of pavements, $4^{\text {th }}$ Edition. Burlington, MA: ButterworthHeinemann.

Although, compaction results are used mostly in highway analysis. The results of MDD and OMC indicate that compaction can give the soils of the slope the needed stability.

\subsection{Permeability}

The ease with which water flows through a porous soil is referred to as permeability. The rate with which water can flow through soils is of interest to soil engineers because in their work they are sometimes required to use soils which inhibit the flow of water and are sometimes required to use soils which facilitate the flow of water [30]. The permeability of soils have a decisive effect on the stability of geotechnical structures, especially slope. According to [7], soils less than $10^{-6} \mathrm{~m} / \mathrm{s}$ are classified as imperious, those between $10^{-6}$ to $10^{-4} \mathrm{~cm} / \mathrm{sec}$ are classified as semi pervious, whereas those greater than $10^{-4} \mathrm{~cm} / \mathrm{sec}$ are classified as pervious. The value of $2 \times 10^{-4} \mathrm{~cm} / \mathrm{sec}$ obtained is a little higher than the value stipulated as semi pervious. The soils of the slope can be classified as pervious. Though not very pervious, but it is pervious enough to encourage instability especially during long period of precipitation.

\subsection{Shear Strength}

Shear strength of a soil is its maximum interval resistance to applied shearing forces. It is the highest stress the soil can resist just before it fails. The shear strength parameters of soils are cohesion and frictional angle. The capability of a soil to support a loading from a structure, to sustain a slope is governed by its shear strength. The shear strength of soil of paramount in the design of foundations, dams, highway, lateral earth pressure problem and particularly stability of slopes and cuts [28].
According to [31], the friction angle is high for a sands than its cohesion and reverse is the case for clay. The low values of angle of internal friction $(14-18)$ and cohesion (4 -10) $\mathrm{kN} / \mathrm{m}^{2}$ indicates that the soil is predominantly silts. The result of shear strength not only revealed that the soil is permeable but also low in shear strength, and prone to instability. This instability can be worsened when saturated and at increase pore water pressure.

\section{Analysis of Slopes Adjacent to the Area of the Slide Using Plaxis 8.6}

Table 6. Strength properties of the slope.

\begin{tabular}{lll} 
Properties & Slope A & Slope B \\
\hline Slope of virgin consolidation line & 0.080 & 0.098 \\
Slope of swelling line & 0.011 & 0.012 \\
Slope of critical state line & 0.54 & 0.51 \\
Dry Unit weight $\left(\mathrm{KN} / \mathrm{m}^{2}\right)$ & 16 & 16 \\
Saturated unit weight $\left(\mathrm{KN} / \mathrm{m}^{2}\right)$ & 19 & 19 \\
Angle of internal friction $(0)$ & 18 & 17 \\
Cohesion $\left(\mathrm{KN} / \mathrm{m}^{2}\right)$ & 4 & 10 \\
Angle of dilactancy $(0)$ & 45 & 51 \\
Void ratio & 0.85 & 0.74 \\
\hline
\end{tabular}

Plaxis 2D was used to perform the numerical analysis for this study. A modified Cam Clay Model (CCM) which is a critical state based soil model was used to assesss the ability of the slopes. This soil model explains the following behaviours of soil: strength, dilatancy and critical state. The boundary condition of the slope was such that the full fixities were applied to the vertical axis and base of the model, but the top of the model or slope surface were not constrained. The zone of influence which is the zone beyond which the applied stress on the slope is negligible was considered before establishing the model domain size. The engineering properties used for the analysis were shown in Table 4.

From the analysis done using Plaxis 8.6 as shown in Figures 4-7, the factors of safety for slopes A and B (see figure 2) are 0.7 and 0.9 which are far below the recommended value of 1.5. The result of the factor of safety obtained is not surprising as their strength properties especially cohesion is between 4 and $10 \mathrm{kN} / \mathrm{m}^{2}$. Another contributing factor is that their slope angles (450 and 510) are greater than their angle of internal friction (180 and 170) respectively.

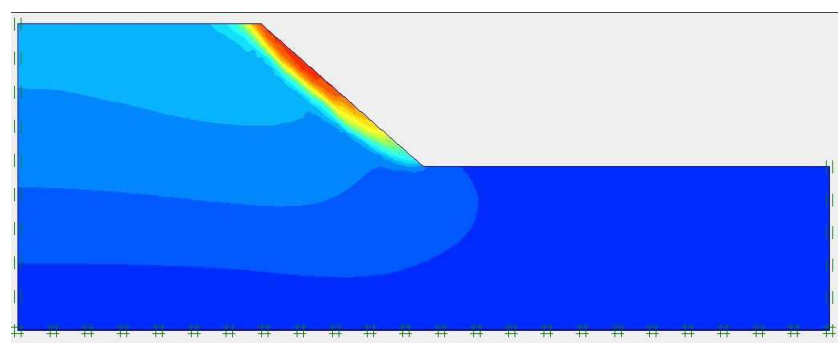

Figure 4. Slope A. 


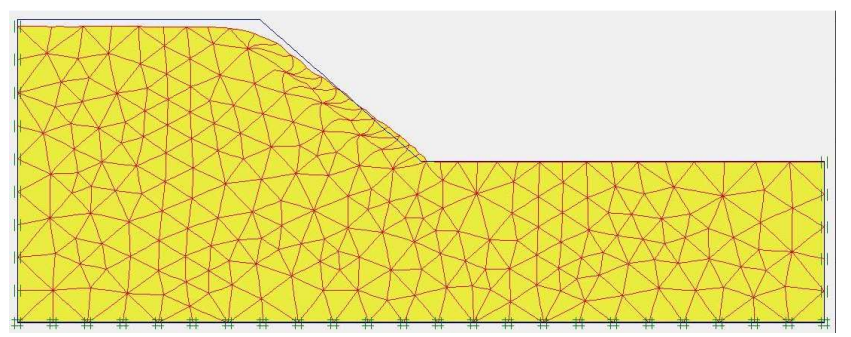

Figure 5. Slope A (Deformed Mesh).

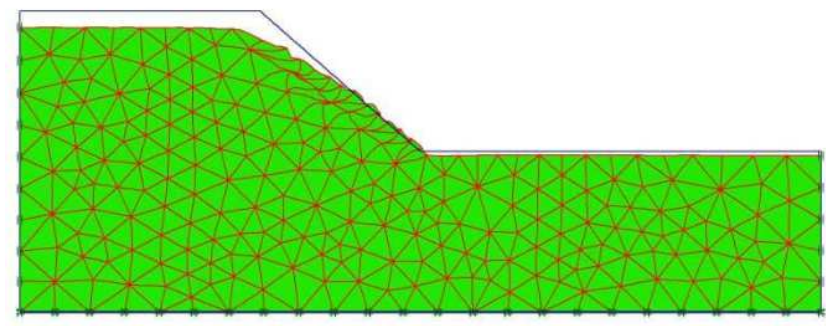

Figure 6. Slope B (Deformed Mesh).

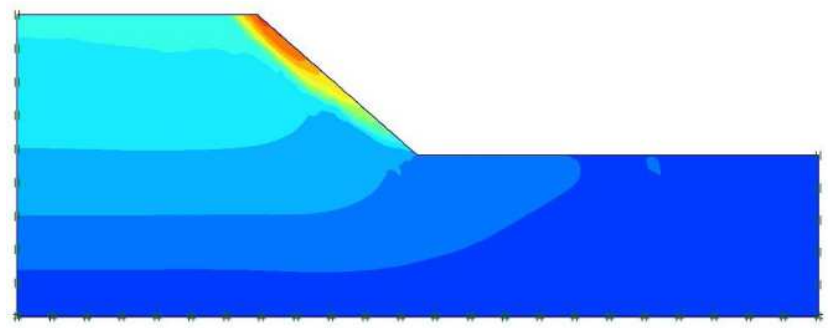

Figure 7. Slope B.

\section{Conclusion}

Preliminary reconnaissance reveals that the slope from which the landslide emanate was a mining excavation site for laterite before the 1960s, which was excessive. Typical with most construction works done in Nigeria, the miners failed to neither restore the land nor re-vegetate the area. This activities lead to the formation of the gully in the area that eventually led to the landslide. Vegetation should be used for slopes which are not steeper than 550. A hard surface stabilization such as shotcrete should be used for steeper slopes. However, suitable landscape measures such as masonry fencing and planer holes construction on the slope surface for planting should be taken to encourage esthetics.

The slopes should be reduced so that the angle of inclination should be at least less than or close to the angle of internal friction where possible. In doing this, the existing vegetation especially trees and shrubs should also be preserved where possible [32-33]. Slope stability engineering works such as cutting back of slope to reduce its gradient, reinforcement (using Reinforced concrete), soil nailing as well as anchors, retaining structures is highly recommended.

Berm should be provided below the toe of the slope to resist movement owing to the possibility of base failure. Enhancing the drainage system is also necessary to reduce seepage forces and the accompanying instability due to pore water pressure. Consolidation by surcharging, electro- osmosis, concrete column, vibroreplacement and terra-probe will enhance stability.

\section{Declarations}

\section{Availability of Data and Material}

The data and materials are available.

\section{Competing Interests}

There is no competing interests associated with the paper.

\section{Authors' Contributions}

i. Emmanuel Arinze: Analysis of Laboratory Results, Plaxis Analysis and writing of the paper.

ii. Ugochukwu Okonkwo: Literature review

iii. Samad Afolabi, Chioma Ahime and Michael Ojobo: Conducted the laboratory work

\section{Acknowledgements}

We acknowledge the Department of Civil Engineering, Michael Okpara University of Agriculture Umudike Nigeria, for making available their laboratory facilities for the geotechnical test.

\section{References}

[1] De Blasio, F. V. (2011). Introduction to physics of landslides. Springer: New York, ISBN 978-94-007-1121-1. https://www.springer.com/gp/book/9789400711211

[2] Terzaghi, K. (2015). Mechanism of landslides. A book Chapter in Application of Geology to Engineering, 83-123. Geological Society of America. Doi: 10.1130/berkey.1950.83.

[3] Malamud, B., Turcotte, F., Guzzetti, F., Reichenbach, P. (2004). Landslides, earthquakes and erosion. Earth and Planetary Science Letters, 229 (1-2): 45-49. https://doi.org/10.1016/j.epsl.2004.10.018.

[4] Clague, J. (2013). Landslides. Encyclopedia of Earth Sciences Series, 1: 594-602. https://www.researchgate.net/profile/John_Clague.

[5] Brunetti, M. T., Guzzetti, F. and Rossi, M. (2009). Probability distributions of landslide volumes. Nonlinear Process Geophysics, 16: 179-188. https://npg.copernicus.org/articles/16/179/2009/

[6] Samia, J., Temme, A., Bregt, B., Wallinga, J., Guzzetti, F. Ardizzone, F. and Rossi, M. (2017). Do landslides follow landslides? Insights in path dependency from a multi-temporal landslide inventory, Landslides, 14: 547-558. https://doi.org/10.1007/s10346-016-0739-x.

[7] USGS (2004). Landslide types and process. Highway Research Board Report, 2004-3072. ISBN: 0309061512. https://pubs.usgs.gov/fs/2004/3072/fs-2004-3072.html

[8] Petley, D, (2012). Global patterns of loss of life from landslides. Geology. $40 \quad$ (10): $\quad 927-930$. https://doi.org/10.1130/G33217.1 
[9] De Blasio, F. V. and Saeter, M. B. (2009). Rolling Friction on a granular medium. Phys Rev E 79: 1 DOI: https://doi.org/10.1103/PhysRevE.79.022301.

[10] Bacic, M., Ivsic, T., Kovacevic, M. S. (2020). Geotechnics of an unavoidable segment of earthquake engineering. Gradjenivar, 72 (10): 923-936.

[11] Bai, S., Lu, P. and Thiebes, B. (2020). Comparing characteristics of rainfall and earthquake triggered landslides in the Upper Minijiang Catchment, China. Engineering Geology, 268 (1055518).

[12] Peruccacci, S., Brunetti, M. T., Gariano, S. L. Melilo, M., Rossi, M., Guzzetti, F. (2017). Rainfall thresholds for possible landslide occurrence in Italy, Geomorphology, 290: 39-57. https://doi.org/10.1016/j.geomorph.2017.03.031

[13] Segoni, S., Piciulo, L. and Gariano, S. (2018). A review of the recent literature on rainfall thresholds for landslide occurrence, Landslides, $15 \quad$ (8): 1483-1501. https://doi.org/10.1007/s10346-018-0966-4.

[14] Jordine, R. J. (2020). Geotechnics, energy and climate change: The 5th Rankine Lecture. Geotechnique, 70 (1): 3-59.

[15] Gariano, S. and Guzzetti, F. (2016). Landslides in a changing climate. Earth-Science Reviews, 162: 227-252. https://doi.org/10.1016/j.earscirev.2016.08.011.

[16] Fanelli G, Salciarini D, Tamagnini C (2016) Reliable soil property maps over large areas: a case study in Central Italy. Environ Eng Geosci 22: 37-52. https://doi.org/10.2113/gseegeosci.22.1.3.

[17] Bicocchi, G., Tofani, V., D’ Ambrosio. M., Tacconi-Steffanelli, C., Vannocci, P., Casagli, N., Lavorini, G., Trevicsani, M, Catani, F. (2019). Geotechnical and hydrological characterization of hillslope deposits for regional landslide prediction modeling Bulletin of Engineering Geology and Environment, 78: 4875-4891.

[18] Bovolenta, R. and Bianchi, D. (2020). Geotechnical analysis and 3D FEM modeling of Ville San Pietro, Geosciences, 10 (11): 473.

[19] Li, Z., Jiang, Y., Tao, Z., He, M. (2019). Monitoring prediction of a rockslide in an open-pit mine and numerical analysis using a material instability criterion. Bulletin of Engineering Geology and Environment, 78: 2041-2053.

[20] Xu, N., Mei, G., Qin, J., Li, Y. and Xu, L.(2021). GeoMfree 3D: A package of meshfree local radial point interpolation method (RPIM) for geomechanics. Computers and Mathematics with applications, 81: 113-132.

[21] Stead, D., Donati, D., Wolter, A. and Sturzenegger, M. (2019). Application of remote sensing to the investigation of rock slopes: Experience gained and lessons learned. ISPRS International Journal of Geo-information, 8 (7): 296.

[22] Zuo, S., Zhao, L., Deng, D., Wang, Z. and Zhao, Z. (2020). Reliability back analysis of landslide shear strength parameters based on general nonlinear failure criterion. International Journal of Rock Mechanics and Mining Sciences, 126 (104189).
[23] Alvioli, M. and Baum RL (2016) Parallelization of the TRIGRS model for rainfall-induced landslides using the message passing interface. Environ Model Softw 81: 122-135. https://doi.org/10.1016/j. envsoft.2016.04.002.

[24] Salciarini D, Fanelli G, Tamagnini C (2017) A probabilistic model for rainfall-induced shallow landslide prediction at the regional scale. Landslides 14: 1731-1746. https://doi.org/10.1007/s10346-017-0812-0.

[25] Tofani V, Bicocchi G, Rossi G, Segoni S, D'Ambrosio M, Casagli N, Catani F (2017). Soil characterization for shallow landslides modeling: a case study in the northern Apennines (Central Italy). Landslides 14: 755-770. https://doi.org/10.1007/s10346-017-0809-8

[26] Salvatici T, Tofani V, Rossi G, D'Ambrosio M, TacconiStefanelli C, Masi EB, Rosi A, Pazzi V, Vannocci P, Petrolo M, Catani F, Ratto S, Stevenin H, Casagli, N (2018). Regional physically based landslide early warning modelling: soil parameterisation and validation of the results. Nat Hazards Earth Syst Sci 18: 1919-1935. https://doi.org/10.5194/nhess18-1919-2018.

[27] Nigeria Erosion and Watershed Management Project, NWEMAP, (2015) "Environmental and Social plan for Amuzukwu Gully Erosion Site Umuahia North LGA, Abia State.

http://documents.worldbank.org/curated/en/119121468323063 328/Environmental-and-social-management-plan-for-theAmuzukwu-Gully-Erosion-Site-Umuahia-North-LGA-AbiaState.

[28] Roy, S. and Bhalla, S. K. (2017). The role of geotechnical properties of soil on civil engineering structures, Resource and Environment, 7 (4): 103-109. doi: 10.5923/j.re.20170704.03.

[29] Budhu, M. (2011). Soil Mechanics and Foundations. John Willy \& Sons: MA. ISBN: 978-0-470-55684-9. https://www.wiley.com/enus/Soil+Mechanics+and+Foundatio ns\%2C+3rd+Edition-p-9780470556849.

[30] Ahaneku, I. E., Arinze, E. E., and Ekeoma, E. C. (2019). Basic Soil Mechanics. Lumen: Umuahia. ISBN 978-978-55892 - 45.

[31] Akayuli, C., Ofusu, B., Nyako, S. O and Opuni, K. O (2013). The influence of observed clay content on shear strength and compressibility of residual sandy soils. International Journal of Engineering Research Application, 3 (4): 2538-2542. doi: 10.1.1.377.7493\&rep=rep1\&type $=$ pdf.

[32] Choi. K. W and Cheung, R. W. (2013). Landslide disaster prevention and mitigation through works in Hong Kong. Journal of Rock Mechanics and Geotechnical Engineering, 5: 354-365. https://doi.org/10.1016/j.jrmge.2013.07.007

[33] HKIE (2003). Soil nails in loose-fill slopes-final report. Hong Kong Geotechnical Division, The Hong Kong Institute of Engineers, 2003. https://www.cedd.gov.hk/filemanager/eng/content_444/design _of_soilnail.pdf 